\title{
Penerapan Terapi Relaksasi Otot Progresif Untuk Menurunkan Tekanan Darah Pada Lansia Yang Mengalami Hipertensi
}

\author{
Jessica Putri Arifiani ${ }^{1 *}$, Dwi Fijianto ${ }^{2}$ \\ 1,2 Program Studi Diploma Tiga Keperawatan, Universitas Muhammadiyah Pekajangan \\ Pekalongan, Indonesia \\ *email: Jesseputri223@gmail.com
}

\begin{abstract}
Hypertension in the elderly is the elderly who experience an increase in blood pressure above normal with a normal range of $120 / 80 \mathrm{mmHg}$ on blood pressure examinion using a blood pressure measuring device. One of the actions to lower blood pressure is the progressive musle relaxation technique. The purpose of this scientific paper is to apply progressive muscle in Proto Tambahrejo village, Bandar sub district,Batang district. Case study method by applying muscle relaxation therapy progressive blood pressure reduction in the elderly with hypertension in Proto Tambahrejo Village Bandar Distract Batang Regency. The data Collection.The results of the application showed that during the 6-day visit, two elderly people were able to lower blood pressure, on the first day the client was $170 / 100 \mathrm{mmHg}$ and the sixth day it was $130 / 90 \mathrm{mmHg}$, while on the second day the client was $160 / 100 \mathrm{mmHg}$ and the sixth day $120 / 90 \mathrm{mmHgm}$ Conclusion This case study shows that progressive muscle relaxation therapy is effective in the elderly with hypertension. Suggestions from the authors are expected that progressive muscle relaxation therapy can be used as an effective application in the elderly who have hypertension.
\end{abstract}

Keywords: Hypertension, Progressive muscle relaxation, the elderly.

\begin{abstract}
Abstrak
Hipertensi pada lansia adalah lansia yang mengalami peningkatan tekanan darah diatas normal yaitu dengan rentang normal $120 / 80 \mathrm{mmHg}$ pada pemeriksaan tensi darah menggunakan alat pengukur tekanan darah.Tindakan untuk menurunkan tekanan darah salah satunya adalah dengan teknik relaksasi otot progersif. Tujuan Karya Tulis Ilmiah ini adalah mengaplikasikan tindakan teknik relaksasi otot progresif untuk menurunkan tekanan darah pada lansia yang mengalami hipertensi. Metode studi kasus dengan menerapkan terapi relaksasi otot progresif untuk menurunkan tekanan darah pada lansia yang mengalami hipertensi. Subyek studi kasus yang digunakan adalah dua lansia yang mengalami hipertensi. Metode pengumpulan data yang digunakan berupa wawancara dan observasi. Hasil penerapan menunjukkan selama 6 hari kunjungan dua lansia mampu menurunkan nyeri tekanan darah, pada klien I hari pertama skala nyeri 7 tekanan darah 170/100 $\mathrm{mmHg}$ dan hari keenam menjadi skala nyeri 1 tekanan darah 130/90 $\mathrm{mmHg}$, Sedangkan pada klien II hari pertama skala nyeri 5 tekanan darah $160 / 100 \mathrm{mmHg}$ dan hari keenam menjadi skala nyeri 1 tekanan darah 120/90 mmHg. Kesimpulan dari studi kasus ini menunjukkan terapi relaksasi otot progresif efektif digunakan untuk menurunkan tekanan darah pada lansia yang mengalami hipertensi.
\end{abstract}

Kata kunci: Hipertensi, relaksasi otot progresif, lansia 


\section{Prosiding Seminar Nasional Kesehatan 2021 Lembaga Penelitian dan Pengabdian Masyarakat Universitas Muhammadiyah Pekajangan Pekalongan}

\section{Pendahuluan}

Hipertensi merupakan keadaan dimana seseorang mengalami peningkatan tekanan darah di atas normal yaitu dengan normal $120 / 80 \mathrm{mmHg}$ yang di tunjukkan oleh angka systolic (bagian atas ) dan angka bawah (diastolic) pada pemeriksaan tensi darah menggunakan alat pengukur tekanan darah Wahdah, (2011). Hipertensi merupakan faktor resiko utama penyakit-penyakit kardiovaskuler yang menyebabkan kematian nomor 3 terbanyak di dunia dan merupakan penyebab kematian tertinggi di Indonesia setelah stroke dan tuberculosis yaitu mencapai 6,8 \%dari populasi kematian di Indonesia. Eriyanti, (2014).

Hipertensi merupakan penyakit yang paling banyak diderita oleh lansia di Indonesia dibuktikan dengan hasil Risekedas, (2013) tentang masalah kesehatan lansia yang tercantum di Infodatin lansia bahwa penyakit hipertensi menempati urutan pertama sebagai penyakit lansia yaitu dengan prevalensi usia 55-64 tahun sebanyak $45,9 \%$, untuk usia 65 -74 tahun sebanyak 57,6 \% dan usia 75 tahun keatas sebanyak $63,8 \%$. Riskesdas, (2013). Faktor faktor yang menyebabkan hipertensi menurut Aulia, (2017) yaitu riwayat keluarga, usia, jenis kelamin, dan rat /etnis. Dan adapun faktor yang dapat diubah yaitu seperti kebiasaan merokok, jarang berolahraga, kebanyakaan mengkonsumi alkohol, kopi, dan makanan yang mengandung garam. Gejala-gejala hipertensi menurut Sutarga, (2017) yaitu sakit kepala, sesak nafas, mimisan, merasa panas di seluruh tubuhnya, sakit dibagian dada, pandangan kabur, dan ada darah di urine nya. Hipertensi yang tidak diatasi dengan baik atau dibiarkan begitu saja akan berdampak serius bagi kesehatan tubuh. Oleh karena itu perlu dilakukan penatalaksanaan yang tepat.

Penatalaksanaan Hipertensi dibagi menjadi dua yaitu dengan cara non farmakologis dan farmakologis. Terapi non farmakologis merupakan terapi tanpa menggunakan obat-obatan dalam proses terapinya, sedangkan terapi farmakologis menggunakan obat atau senyawa yang dalam kerjanya dapat menurunkan tekanan darah pasien Triyanto, (2014). Pemberian terapi non farmakologis diantaranya yaitu pemberian pijatan, yoga, pengobatan herbal pernafasan dan relaksasi relaksasi otot progresif Bulecheck, (2013). Terapi relaksasi otot progresif dapat meningkatkan relaksasi dengan menurunkan aktivitas saraf simpatis dan meningkatkan relaksasi aktifitas saraf parasimpatis sehingga terjadi vasodilatasi diameter arterol Muttaqin, (2014). Relaksasi otot progresif juga bersifat vasodilator yang efeknya memperlebar pembuluh darah dan dapat menurunkan tekanan darah secara langsung. Relaksasi ini menjadi metode relaksasi termurah,tidak ada efek samping mudah dilakukan, membuat tubuh dan pikiran terasa tenang dan rileks Jacob, (2010) dalam Erwanto, (2017). Berdasarkan survey pendahuluan bahwa terapi relaksasi otot progresif (ROP) pada lansia hipertensi di Jambi pernah dilakukan pada penelitian sebelumnya namun belum melihat keefektifan terapi ROP dengan terapi farmakologis. Tujuan dari penelitian ini adalah untuk mengetahui keefektifan terapi relaksasi otot progresif terhadap tekanan darah pada lansia penderita hipertensi di Panti Sosial Tresna Werdha Budi Luhur Jambi.

Berdasarkan latar belakang diatas, penulis tertarik untuk menerapkan intervensi terapi relaksasi otot progresif. Penulis berharap intervensi teknik relaksasi otot 


\section{Prosiding Seminar Nasional Kesehatan 2021 Lembaga Penelitian dan Pengabdian Masyarakat Universitas Muhammadiyah Pekajangan Pekalongan}

progresif dapat diterapkan sebagai sarana pengendalian secara non farmakologis untuk menurunkan tekanan darah pada lansia yang mengalami hipertensi.

Berdasarkan uraian diatas tujuan studi kasus ini untuk melihat adakah pengaruh terapi relaksasi otot progresif teradap tekanan darah lansia penderita hipertensi.

\section{Metode}

Rancangan Karya Tulis Ilmiah ini menggunakan metode deskriptif. Metode deskriptif dengan desain studi kasus adalah salah satu jenis metode yang digunakan untuk menganalisis data dengan cara mendeskripsikan atau menggambarkan data yang telah terkumpul sebagaimana adanya tanpa bermaksud membuat kesimpulan yang berlaku untuk umum atau generalisasi.Studi kasus dalam karya tulis ilmiah ini adalah tentang penerapan teknik relaksasi otot progresif dalam menurunkan hipertensi pada lansia. (Lalage, 2015).

Subjek dalam studi kasus ini adalah dua klien lansia dengan hipertensi yang diamati secara mendalam dengan dilakukan asuhan keperawatan yang komperhensif bersamaan dengan diberikan latiihan teknik relaksasi otot progresif pada lansia yang mengalami hipertensi. Kriteria inklusi meliputi lansia hipertensi berusia 60 - 70 tahun, lansia yang sedang tidak mengkonsumsi obat, lansia yang bersedia menjadi responden dalam penelitian. Sedangkan kriteria ekslusi lansia yangmengalami penurunan pendengaran dana penglihatan. Fokus penulisan pada karya tulis ilmiah ini adalah penerapan teknik relaksasi otot progresif untuk menurunkan tekanan darah pada lansia yang mengalami hipertensi. Penulis melaksanakan bertempat di Desa Proto Tambahrejo Kecamatan Bandar Kabupaten Batang.

\section{Hasil dan Pembahasan}

Hasil

a. Klien I (Ny. T)

Hasil pengkajian yang dilakukan pada tanggal 21 maret 2021 pukul 13.00 WIB di rumah Ny T di Desa Proto Tambahrejo. Dari hasil wawancara diperoleh data identitas klien yaitu Ny. T, umur 65 tahun, alamat Desa Proto Tambahrejo Kecamatan Bandar, pendidikan terakhir Sekolah Dasar, klien beragama islam, klien tinggal bersama suami yaitu Tn. K, berumur 73 tahun, Ny.T memiliki 4 orang anak sudah menikah semua. Anak pertama Ny. T yaitu Ny I umur 47 tahun, anak kedua Tn A. Umur 44 tahun, anak ketiga Tn.A umur 40 tahu, Anak keempat 25 tahun.Tipe keluarga Ny. T adalah kelurga inti yaitu dalam satu keluarga terdiri dari ayah, ibu, dan anak. Keluarga Ny $\mathrm{T}$ beragama islam dan bersuku jawa, pendapatan Ny. T sebagai penjual warung sembako dan $\mathrm{Tn}$. $\mathrm{K}$ sebagai penjual bibit pisang kurang lebih 2.000.000.,-perbulan.

Keluhan utama klien mengatakan pusing, riwayat penyakit sekarang sudah 3 hari klien mengatakan sering pusing dan nyeri pada tengkuknya. Riwayat penyakit dahulu, klien mengatakan pernah mengalami gejala stroke ringan. Klien mengatakan tidak memppunyai penyakit menular.

Hasil pemeriksaan fisik didapatkan kesadaran umum compos mentis TD : 170/100 mmHg, Nadi: 90x/menit, RR:24x/menit, Suhu: 36,50 C, BB 60 kg, TB 159 $\mathrm{cm}$. Dari fokus pemeriksaan didapatkan hasil paru paru Inspeksi : bentuk dada 


\section{Prosiding Seminar Nasional Kesehatan 2021 Lembaga Penelitian dan Pengabdian Masyarakat Universitas Muhammadiyah Pekajangan Pekalongan}

simetris, tidak ada lesi, palpasi tidak ada nyeri tekan, tidak ada benjolan, perkusi bunyi paru normal, Auskultasi suara normal vesikuler, tidak ada pembesaran jantung.

Intervensi keperawatan yang ditegakkan berdasarkan diagnosa keperawatan yang muncul antara lain sebagai berikut : Lakukan pengkajian nyeri secara komprehensif, monitor TTV sebelum dan sesudah pemberian terapi relaksasi otot progresif, ajarkan teknik relaksasi nafas dalam, berikan terapi relaksasi otot progresif. Setelah dilakukan tindakan keperawatan selama 6 kali kunjungan diharapkan masalah nyeri dapat teratasi, dengan kriteria hasil klien mengatakan nyeri berkurang, tanda tanda vital dalam batas normal, skala nyeri berkurang menjadi 1 , klien tampak rileks dan tampak nyaman.

\section{b. Klien II ( Ny. W)}

Hasil pengkajian yang dilakukan pada tanggal 21 maret 2021 pukul 13.00 WIB di rumah Ny W di Desa Proto Tambahrejo. Dari hasil wawancara diperoleh data identitas klien yaitu Ny. W, umur 68 tahun, alamat Desa Proto Tambahrejo Kecamatan Bandar, pendidikan terakhir Sekolah Dasar, klien beragama islam, klien tinggal bersama suami yaitu Tn. A, berumur 77 tahun, Ny.W memiliki 3 orang anak sudah menikah semua. Anak pertama Ny. W yaitu Ny T umur 50 tahun, anak kedua Ny M. Umur 42 tahun, anak ketiga Tn.E umur 32 tahun. Keluarga Ny W beragama islam dan bersuku jawa, pendapatan Ny. W sebagai ibu rumah tangga dan Tn. A sebagai penjual sayuran di pasar kurang lebih 1.000.000.,-perbulan.

Keluhan utama klien mengatakan pusing, riwayat penyakit sekarang klien mengatakan sudah seminggu mengeluh pusing dan nyeri pada tengkuknya. Riwayat penyakit dahulu, klien mengatakan tidak punya masalah penyakit dahulu. Klien mengatakan tidak memppunyai penyakit menular.

Hasil pemeriksaan fisik didapatkan kesadaran umum compos mentis TD : 160/100 mmHg, Nadi: 80x/menit, RR:24x/menit, Suhu: 36,5o C, BB 55 kg, TB 150 $\mathrm{cm}$. Dari fokus pemeriksaan didapatkan hasil paru paru Inspeksi : bentuk dada simetris, tidak ada lesi, palpasi tidak ada nyeri tekan, tidak ada benjolan, perkusi bunyi paru normal, Auskultasi suara normal vesikuler, tidak ada pembesaran jantung.

Intervensi keperawatan yang ditegakkan berdasarkan diagnosa keperawatan yang muncul antara lain sebagai berikut : Lakukan pengkajian nyeri secara komprehensif, monitor TTV sebelum dan sesudah pemberian terapi relaksasi otot progresif, ajarkan teknik relaksasi nafas dalam, berikan terapi relaksasi otot progresif. Setelah dilakukan tindakan keperawatan selama 6 kali kunjungan diharapkan masalah nyeri dapat teratasi, dengan kriteria hasil klien mengatakan nyeri berkurang, tanda tanda vital dalam batas normal, skala nyeri berkurang menjadi 1 , klien tampak rileks dan tampak nyaman.

\section{Pembahasan}

Hasil studi kasus menunjukan bahwa tindakan terapi relaksasi otot progresif dapat menurunkan tekanan darah. Tindakan non farmakologi pada pasien hipertensi yang mengalami nyeri berupa tindakan terapi relaksasi otot progresif. Tindakan tersebut 


\section{Prosiding Seminar Nasional Kesehatan Lembaga Penelitian dan Pengabdian Masyarakat Universitas Muhammadiyah Pekajangan Pekalongan}

digunakan untuk menurunkan tekanan darah. Tindakan terapi relaksasi otot progresif dilakukan setiap pagi hari dalam waktu 30 menit, Triyanto, (2014).

Hasil studi kasus menunjukan bahwa tindakan terapi relaksasi otot progresi dapat menurunkan tekanan darah. Tindakan terapi relaksasi otot progresif ini efektif untuk digunakan pada pasien hipertensi. Penelitian ini dilakukan Luhur, (2019) Dengan latihan yang benar dan didukung dengan teori bahwa melakukan terapi relaksasi otot progesif selama 6 hari secara berturut turut selama 30 menit mampu membantu menurunkan tekanan darah tinggi pada lansia yang menderita hipertensi.

Hasil studi kasus menunjukan bahwa terapi relaksasi otot progresif dapat menurunkan tekanan darah. Penelitian yang dilakukan Scanlon \& Sundres (2011) Dengan melakukan terapi relaksasi otot progresif dengan cara meregangkan dan merilekskan otot secara sadar otot akan memendek sehingga terjadi kontraksi pada seluruh otot. Pada saat melakukan terapi relaksasi otot progresif terbukti dapat memberikan efek rileks yang pada akhirnya berpengaruh terhadap tekanan darah yaitu dapat menurunkan tekanan darah atau mengontrol tekanan darah pada lansia yang mengalami hipertensi.

\section{Kesimpulan}

Penerapan terapi relaksasi otot progresif pada 2 subjek studi kasus dapat menurunkan tekanan darah pada lansia hipertensi, Hasil pengkajian yang dilakukan pada lansia dengan hipertensi didapatkan bahwa lansia yang mengalami keluhan pusing kepala, nyeri ditengkuk belakang, klien I TD : 170/100 mmHg dan klien II TD :160/100 mmHg, diagnosa keperawatan yang muncul pada studi kasus didapatkan diagnosa keperawatan utama yaitu nyeri akut, Intervensi keperawatan yang direncanakan pada studi kasus untuk nyeri secara komprehensif, monitor TTV, ajarkan teknik relaksasu nafas dalam, berikan terapi relaksasi otot progresif, tingkatkan istirahat, Implementasi keperawatan yang dilakukan pada studi kasus ini yaitu memberikan terapi relaksasi otot progresif untuk menurunkan tekanan darah pada lansia.

Evaluasi yang telah penulis lakukan pada kedua lansia yang mengalami hipertensi selama 6 kali pertemuan, data obyektif yang didapatkan pada klien I dan klien II mengalami penurunan tekanan darah setelah diberikan tindakan terapi relaksasi otot progresif yaitu pada klien I pertemuan pertama TD awal 170/100 $\mathrm{mmHg}$, skala nyeri 7 , klien mengatakan nyeri pada tengkuk. Pertemuan keenam menjadi 130/90 mm skala nyeri 1 , klien mengatakan nyeri berkurang. Dan pada klien II pertemuan pertama $160 / 100 \mathrm{mmHg}$, skala nyeri 5, klien mengatakan nyeri pada tengkuk nya. Pertemuan hari keenam menjadi $120 / 90 \mathrm{mmHg}$, skala nyeri 1 , klien mengatakan nyeri berkurang. Hal ini sama dengan hasil penelitian yang dilakukan Rosyid dan Hernawan (2017) dengan judul pengaruh terapi relaksasi otot progresif untuk menurunkan tekanan darah lansia yang mengalami hipertensi di Panti Werdha Dharma Bhakti Surakarta bahwa pemberian terapi relaksasi otot progresif berpengaruh untuk menurunkan tekanan darah. 


\section{Prosiding Seminar Nasional Kesehatan Lembaga Penelitian dan Pengabdian Masyarakat Universitas Muhammadiyah Pekajangan Pekalongan

\section{Referensi}

[1] Akhati, A. Pengaruh teknik relaksasi otot progresif terhadap penurunan hipertensi pada lansia di Mojokerto program studi ilmu keperawatn fakultas ilmu kesehatan STIKES Pemkab Jombang, 2019 Di ambil darihttps://scholar.google.com/

[2] Aulia. (2017). Faktor- faktor hipertensi. Jakarta : Gramedia Pustaka Utama.

[3] Bulecheck. (2016). Efektifitas Efektivitas terapi relaksasi ototprogresif dalam menurunkan hipertensi pada lansia. Prodi S1 keperawatan, Sekolah Tinggi Ilmu Kesehatan Baiturrahim, 2016. Jurnal academia baiturrahim vol.8 No. 1, Maret 2019. ISSBN 2654-2552. Diambil dari https://scholar.google.com/

[4] Eriyanti. (2014). Pengaruh Relaksasi Otot Progresif Untuk Menrunkan Tekanan Darah. Jurnal Kesehatan, vol. 10. No. 2 Maret 2014. 2014 Di ambil https://scholar.google.com/

[5] Erwanto. Metodologi penelitian ilmu keperawatan, pendekatan praktis Jagakars Jakarta selatan, 2017. Salemba Medika.

[6] Jacob. (2010). Keperawatan gerontik.Prenggan Kotagede.Sarowajan

[7] Lalage. (2010). Efektifitas Efektivitas terapi relaksasi ototprogresif dalam menurunkan hipertensi pada lansia. Prodi S1 keperawatan, Sekolah Tinggi Ilmu Kesehatan Baiturrahim, 2016. Jurnal academia baiturrahim vol.8 No. 1, Maret 2019. ISSBN 2654-2552. Diambil dari https://scholar.google.com/

[8] Luhur. (2019). Efektifitas Efektivitas terapi relaksasi ototprogresif dalam menurunkan hipertensi pada lansia. Prodi S1 keperawatan, Sekolah Tinggi Ilmu Kesehatan Baiturrahim, 2016. Jurnal academia baiturrahim vol.8 No. 1, Maret 2019. ISSBN 2654-2552. Diambil dari https://scholar.google.com/

[9] Masniati. (2013). Pengaruh Relaksasi Otot Progresif Untuk Menrunkan Tekanan Darah. Jurnal Kesehatan, vol. 10. No. 2 Maret 2014. 2014 Di ambil https://scholar.google.com/

[10] Nurarif \& Kusuma. Aplikasi Asuhan Keperawatan berdasarkan diagnosa medis \& NANDA NIC-NOC. Bantul Yogyakarta : Mediaction.

[11] Snyder \& Linquist. (2010). Pengaruh terapi relaksasi otot progresif terhadap penurunan tekanan darah lansia dengan hipertensi di Panti Werdha Drama Bhakti Kelurahan Pajang Surakarta. Jurnal Kesehatan Vol. 10 2017. Diambil dari https://scholar.google.com/

No. 1 Juni 